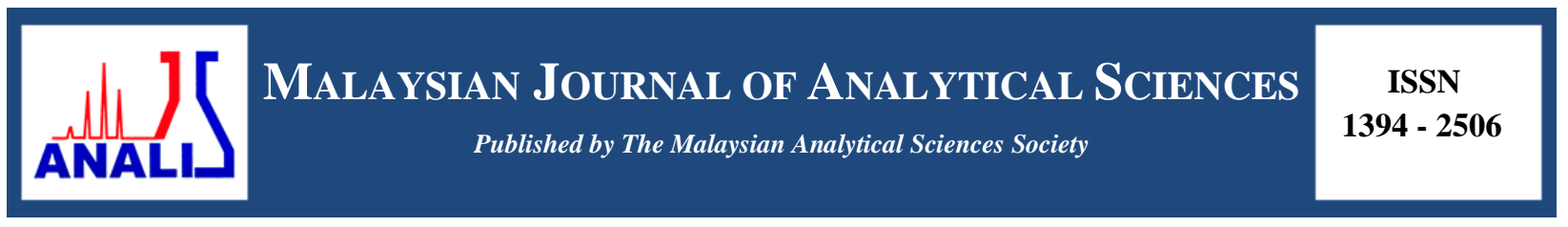

\title{
WATER EXTRACT OF ONION PEEL ASH: AN EFFICIENT GREEN CATALYTIC SYSTEM FOR THE SYNTHESIS OF ISOINDOLINE-1,3-DIONE DERIVATIVES
}

\author{
(Air Abu Kulit Bawang: Sistem Pemangkin Katalitik Hijau yang Effisien dalam Sintesis \\ Terbitan Isoindolina-1,3-dion) \\ Poh Wai Chia ${ }^{1,2}$, Poh Seng Chee ${ }^{1}$, Mohd Haziq Aziz ${ }^{1}$, Siti Aisha Mohd Radzi ${ }^{2}$, Fu Siong Julius Yong ${ }^{2}$, \\ $\mathrm{Su}-$ Yin $\mathrm{Kan}^{3}$ \\ ${ }^{1}$ School of Marine and Environmental Sciences \\ ${ }^{2}$ Institute of Marine Biotechnology \\ Universiti Malaysia Terengganu, 21030 Kuala Nerus, Terengganu, Malaysia \\ ${ }^{3}$ Faculty of Health Sciences, \\ Universiti Sultan Zainal Abidin, 21300 Kuala Nerus, Terengganu, Malaysia. \\ *Corresponding author: pohwai@umt.edu.my
}

Received: 2 July 2018; Accepted: 27 November 2018

\begin{abstract}
Isoindoline-1,3-dione derivatives are important organic compounds associated with various interesting applications such as in the fields of material science, medicine, important building blocks and so on. Traditionally, the synthesis of isoindoline-1,3-dione derivatives are achieved using harmful and toxic catalysts, such as concentrated sulphuric acid, triphenylphosphine, ionic liquid [bmim $]\left[\mathrm{BF}_{4}\right]$ or phthalimide-N-sulfonic acid. Thus, the development of a greener catalytic system for the synthesis of isoindoline-1,3-dione derivatives is highly sought after. In this work, an efficient synthesis of isoindoline-1,3-dione derivatives using the Water Extract of Onion Peel Ash (WEOPA) method is described. The new approach provides several advantages including the non-usage of external acids, recyclable catalytic system, cheap and the yield of the synthesized products were obtained in moderate to good yields by reacting various anilines with phthalic anhydride. The current improved method is scientifically important, due to it avoid the use of environmental harmful reagents and at the same time provides an alternative method for bio-waste management.
\end{abstract}

Keywords: water extract of onion peel ash, isoindoline-1,3-dione, recyclable catalytic system, anilines, phthalic anhydride

\begin{abstract}
Abstrak
Terbitan isoindolina-1,3-dion adalah sebatian organik yang penting dan dikaitkan dengan pelbagai aplikasi yang menarik, seperti dalam bidang sains bahan, perubatan, blok bangunan penting dan sebagainya. Secara tradisinya, sintesis derivatif isoindolina1,3-dion dicapai dengan menggunakan pemangkin berbahaya dan beracun, seperti asid sulfurik pekat, trifenilfosfin, cecair ionik [bmim $]\left[\mathrm{BF}_{4}\right]$ atau asid fitalimid-N-sulfonik. Oleh itu, pembangunan sistem pemangkin yang lebih hijau untuk sintesis derivatif isoindolina-1,3-dion sangat diperlukan. Dalam kerja ini, satu kaedah effisien dalam sintesis terbitan isoindolina-1,3-dion dengan menggunakan ekstrak air abu bawang dibincangkan disini. Kaedah baru ini memberikan pelbagai manfaat termasuk bebas daripada penggunaan asid luaran, sistem pemangkin kitar semula, murah dan hasil bagi produk sintesis yang didapati adalah sederhana hingga baik melalui tindak balas antara anilin-anilin dengan fitalik anhidrit. Kaedah yang ditambahbaik ini adalah penting secara saintifik, kerana ia mengelakkan penggunaan reagen berbahaya kepada alam sekitar dan pada masa yang sama menyediakan kaedah alternatif untuk pengurusan bio-sisa.
\end{abstract}

Kata kunci: ekstrak air abu bawang merah, isoindolina-1,3-dion, system pemangkin kitar semula, anilin, fitalik anhidrit 


\section{Introduction}

Lately, there has been growing interest among chemists to develop simple and efficient green protocols for performing organic reactions due to the increase in environmental awareness worldwide [1-4]. The use of environmentally acceptable reagents, green solvents and biocatalysts are favorable, as it promote sustainable chemistry for synthesis processes conducted in both academic institutions and industries [5]. In particular, the use of aqueous media as green solvent has attracted the attention of the scientific community due to its environmentalfriendly, cheap, benign solvent, non-flammability and readily available features, thus rendering its usefulness in the field of organic synthesis [6-8]. Furthermore, the use of water as a solvent in organic processes is promising and it is known to provide acceleration in the rate of chemical reactions as evidenced in a few recent literature [9-11].

At present, there has been growing awareness among synthetic chemists to utilize waste water, water extract of biowastes and vegetables juices to address and apply the concept of eco-friendly organic transformations. Among the main benefits identified from employing these green protocols include the biodegradable/recyclable nature and high catalytic activity of these green catalytic systems in organic transformations [12]. To date, numerous organic transformations have been carried out efficiently using these green and recyclable catalytic systems. Examples include the Suzuki-Miyaura reaction [13], synthesis of biaryls [14], Sonogashira reaction [15], Henry reaction [16], Dakin reaction [17] and so on. Based on a survey, the world generates approximately a million tons of bio-wastes monthly [18]. The rate of generation of bio-wastes is expected to escalate over time with the boom in world population [19]. From the perspective of green chemistry, unwanted wastes such as agricultural and food wastes are attractive resources as they are abundantly available and have the potential to become green catalytic systems in chemical processes.

Onions (Allium cepa L.) is one of the most important vegetable crops cultivated worldwide for culinary and other functional purposes [20]. In some developed countries, it is reported that more than 100,000 tons of onion waste are generated annually [21]. This bio-waste could adversely affect our environment and living organisms if it is sent directly to landfill without proper treatment [22]. As part of our continuous interest to develop green synthetic methodologies, we herein report on a simple, recyclable catalytic system and efficient protocol for the synthesis of isoindoline-1,3-dione derivatives using the Water Extract of Onion Peel Ash (WEOPA) (Scheme 1). Isoindoline1,3-dione derivatives have found many attractive applications in material science [23], medicine [24], important building block [25] and so on. Traditionally, the synthesis of isoindoline-1,3-dione derivatives are achieved using harmful and toxic catalysts, such as the concentrated sulfuric acid [26] and triphenylphosphine [27]. Other methods are by using ionic liquid [bmim] $\left[\mathrm{BF}_{4}\right]$ [28] and phthalimide- $N$-sulfonic acid [29], which entail the use of expensive reagents. The use of the WEOPA as a catalytic system to catalyze the synthesis of isoindoline-1,3-dione derivatives can reduce the environmental pressure exerted by bio-wastes. In addition, this work enables the development of a more sustainable synthesis that is of scientific significance and at the same time, overcome the aforementioned drawbacks.<smiles>O=C1OC(=O)c2ccccc21</smiles>

1<smiles>Nc1ccc(Br)cc1</smiles>

2
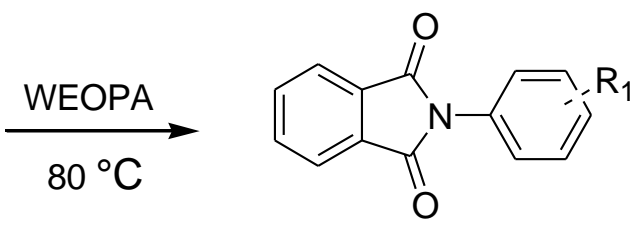

$3 a-3 i$

Scheme 1. Synthetic route towards the preparation of isoindoline-1,3-dione derivatives in the presence of WEOPA

\section{Materials and Methods}

All chemicals and solvent were purchased from Sigma-Aldrich and Merck, were used without further purification. The ${ }^{1} \mathrm{H}$ and ${ }^{13} \mathrm{C}$-NMR experiments were recorded using $\mathrm{CDCl}_{3}$ as solvent on a Bruker Avance III 400 spectrometer and the chemical shifts were given in parts per million (ppm). The GC-MS analyses were recorded using a 
Shimadzu QP2010SE, equipped with a Supelco fused silica capillary column $(30 \mathrm{~m} \times 0.25 \mathrm{~mm}$ i.d., $0.25 \mathrm{~mm}$ film thickness). The metal content was characterized using Varian Vista Pro Inductive Coupled Plasma Optical Emission Spectroscopy (ICP-OES).

\section{Preparation of the water extract of onion peel ash}

Onion waste was obtained from a nearby local waste disposal site at Kuala Nerus, Malaysia in March 2018. The outer layer and bulb of onion peel were separated, and the onion peel was washed with distilled water. The onion peels were then sliced into small pieces and air-dried for 2-3 days. The WEOPA catalytic system was prepared according to a previous method [12]. Initially, the dried peels $(2.5 \mathrm{~g})$ were burnt in the furnace at $500{ }^{\circ} \mathrm{C}$ for about 1 hour. The obtained ash was transferred into a $100 \mathrm{~mL}$ shake flask containing $25 \mathrm{~mL}$ of distilled water and the mixture was stirred for 1 hour. Subsequently, the mixture was filtered using Whatman filter paper No.1 and the resulting filtrate was termed as WEOPA.

\section{General procedure for the synthesis of isoindoline-1,3-dione derivatives.}

A $25 \mathrm{~mL}$ round bottom flask containing a mixture of phthalic anhydride $(1.00 \mathrm{mmol})$ and aniline $(1.00 \mathrm{mmol})$ was added with WEOPA $(2 \mathrm{~mL})$. The reaction mixture was stirred magnetically at $110 \mathrm{rpm}$ and heated up to $80{ }^{\circ} \mathrm{C}$. The progress of the reaction was monitored using Thin-Layer Chromatography (TLC). Upon the completion of the reaction, ethyl acetate $(3 \times 30 \mathrm{~mL})$ was added into the mixture to extract the crude products. The organic layer was combined and dried with $\mathrm{MgSO}_{4}$, before concentrated under reduced pressure. The crude product was purified over silica gel column chromatography with ethyl acetate/hexane (1:9) as its eluent. The aqueous recovered WEOPA was reused for the synthesis of other isoindoline-1,3-dione derivatives under identical condition.

\section{Spectroscopic data of isoindoline-1,3-dione derivatives}

\section{Results and Discussion}

2-phenyl isoindoline-1,3-dione 3a ${ }^{1} \mathrm{H}-\mathrm{NMR}\left(400 \mathrm{MHz}, \mathrm{CDCl}_{3}\right)$ : $\delta$ 7.47-7.37 (m, 3H); 7.56-7.47 (m, 2H); 7.85-7.74 $(\mathrm{m}, 2 \mathrm{H}) ; 8.02-7.90(\mathrm{~m}, 2 \mathrm{H}) \mathrm{ppm} ;{ }^{13} \mathrm{C} \mathrm{NMR}\left(100 \mathrm{MHz}, \mathrm{CDCl}_{3}\right) \delta 123.76,126.61,128.07,129.19,131.67,131.82$, 134.38, 167.34 ppm; GC-MS: $\mathrm{C}_{14} \mathrm{H}_{9} \mathrm{NO}_{2}, \mathrm{~m} / \mathrm{z} 223.06(\mathrm{M})^{+}$.

2-(o-tolyl) isoindoline-1,3-dione 3b ${ }^{1} \mathrm{H}-\mathrm{NMR}\left(400 \mathrm{MHz}, \mathrm{CDCl}_{3}\right): \delta 2.21(\mathrm{~s}, 3 \mathrm{H}) ; 7.20(\mathrm{~d}, J=7.5 \mathrm{~Hz}, 1 \mathrm{H}) ; 7.29$ $7.40(\mathrm{~m}, 3 \mathrm{H}) ; 7.83 .-7.76(\mathrm{~m}, 2 \mathrm{H}) ; 7.72-8.00(\mathrm{~m}, 2 \mathrm{H}) \mathrm{ppm} ;{ }^{13} \mathrm{C} \mathrm{NMR}\left(100 \mathrm{MHz}, \mathrm{CDCl}_{3}\right) \delta 18.0,123.82,126.86$, $128.83,129.47,130.60,131.18,132.11,134.46,136.59,167.41 \mathrm{ppm}$; GC-MS: $\mathrm{C}_{15} \mathrm{H}_{11} \mathrm{NO}_{2,} \mathrm{~m} / \mathrm{z} 237.08(\mathrm{M})^{+}$.

2-( $m$-tolyl) isoindoline-1,3-dione 3c ${ }^{1} \mathrm{H}-\mathrm{NMR}\left(400 \mathrm{MHz}, \mathrm{CDCl}_{3}\right)$ : $\delta 2.42(\mathrm{~s}, 3 \mathrm{H}) ; 7.24-7.18(\mathrm{~m}, 3 \mathrm{H}) ; 7.42-7.36(\mathrm{~m}$, $1 \mathrm{H}) ; 7.83-7.74(\mathrm{~m}, 2 \mathrm{H}) ; 7.79-7.91(\mathrm{~m}, 2 \mathrm{H}) \mathrm{ppm} ;{ }^{13} \mathrm{C} \mathrm{NMR}\left(100 \mathrm{MHz}, \mathrm{CDCl}_{3}\right) \delta 21.41,123.66,123.82,127.31$, 129.01, 129.13, 131.48, 131.82, 134.40, 139.21, 167.44 ppm; GC-MS: $\mathrm{C}_{15} \mathrm{H}_{11} \mathrm{NO}_{2}, \mathrm{~m} / \mathrm{z} 237.08(\mathrm{M})^{+}$.

2-(m-tolyl) isoindoline-1,3-dione 3d ${ }^{1} \mathrm{H}-\mathrm{NMR}\left(400 \mathrm{MHz}, \mathrm{CDCl}_{3}\right): \delta 2.40(\mathrm{~s}, 3 \mathrm{H}) ; 7.30(\mathrm{~s}, 4 \mathrm{H}) ; 7.82-7.76$ (m, 2H); 7.98-7.92 (m, 2H) ppm; ${ }^{13} \mathrm{C}$ NMR $\left(100 \mathrm{MHz}, \mathrm{CDCl}_{3}\right) \delta 21.33,123.65,126.51,129.02,129.83,131.88,134.42$, 138.20, 167.45 ppm; GC-MS: $\mathrm{C}_{15} \mathrm{H}_{11} \mathrm{NO}_{2,} \mathrm{~m} / \mathrm{z} 237.08(\mathrm{M})^{+}$.

2-(4-methoxyphenyl) isoindoline-1,3-dione 3e ${ }^{1} \mathrm{H}-\mathrm{NMR}\left(400 \mathrm{MHz}, \mathrm{CDCl}_{3}\right): \delta 3.85$ (s, 3H); $7.02(\mathrm{~d}, J=8.7 \mathrm{~Hz}$, $2 \mathrm{H}) ; 7.33(\mathrm{~d}, J=9.1 \mathrm{~Hz}, 2 \mathrm{H}) ; 7.83-7.73(\mathrm{~m}, 2 \mathrm{H}) ; 8.00-7.90(\mathrm{~m}, 2 \mathrm{H}) \mathrm{ppm} ;{ }^{13} \mathrm{C}$ NMR $\left(100 \mathrm{MHz}, \mathrm{CDCl}_{3}\right) \delta 55.46$, 114.46, 123.68, 124.31, 128.02, 131.83, 134.30, 159.29, 167.61 ppm; GC-MS: $\mathrm{C}_{15} \mathrm{H}_{11} \mathrm{NO}_{3,} \mathrm{~m} / \mathrm{z} 253.07(\mathrm{M})^{+}$.

2-(4-isopropylphenyl) isoindoline-1,3-dione 3f ${ }^{1} \mathrm{H}-\mathrm{NMR}$ (400 MHz, $\left.\mathrm{CDCl}_{3}\right): \delta 1.31(\mathrm{~d}, J=7.1 \mathrm{~Hz}, 6 \mathrm{H}) ; 3.06-2.90$ $(\mathrm{m}, 1 \mathrm{H}) ; 7.37(\mathrm{~d}, J=1.2 \mathrm{~Hz}, 4 \mathrm{H}) ; 7.85-7.74(\mathrm{~m}, 2 \mathrm{H}) ; 8.03-7.70(\mathrm{~m}, 2 \mathrm{H}) \mathrm{ppm} ;{ }^{13} \mathrm{C} \mathrm{NMR}\left(100 \mathrm{MHz}, \mathrm{CDCl}_{3}\right) \delta 24.03$, $34.01,123.68,126.67,126.51,127.27,129.21,131.91,134.42,148.94,167.48 \mathrm{ppm} ; \mathrm{GC}-\mathrm{MS}: \mathrm{C}_{17} \mathrm{H}_{15} \mathrm{NO}_{2}, \mathrm{~m} / \mathrm{z}$ $265.11(\mathrm{M})^{+}$.

2-(4-fluorolphenyl) isoindoline-1,3-dione 3g ${ }^{1} \mathrm{H}-\mathrm{NMR}\left(400 \mathrm{MHz}, \mathrm{CDCl}_{3}\right): \delta 7.20(\mathrm{t}, 2 \mathrm{H}) ; 7.83-7.36(\mathrm{~m}, 2 \mathrm{H}) ; 7.80$ $(\mathrm{dd}, J=5.3 \mathrm{~Hz}, J=3.0 \mathrm{~Hz}, 2 \mathrm{H}) ; 7.95(\mathrm{dd}, J=5.3 \mathrm{~Hz}, J=3.0 \mathrm{~Hz}, 2 \mathrm{H}) \mathrm{ppm} ;{ }^{13} \mathrm{C} \mathrm{NMR}\left(100 \mathrm{MHz}, \mathrm{CDCl}_{3}\right) \delta 115.96$, 
Chia et al: WATER EXTRACT OF ONION PEEL ASH: AN EFFICIENT GREEN CATALYTIC SYSTEM FOR THE SYNTHESIS OF ISOINDOLINE-1,3-DIONE DERIVATIVES

$116.31,123.82,127.63,128.39,128.43,131.70,134.54,160.71,163.23,167.21 \mathrm{ppm} ; \mathrm{GC}-\mathrm{MS}: \mathrm{C}_{14} \mathrm{H}_{8} \mathrm{FNO}_{2,} \mathrm{~m} / \mathrm{z}$ $241.05(\mathrm{M})^{+}$.

2-(4-chlorophenyl) isoindoline-1,3-dione $3 \mathbf{h}{ }^{1} \mathrm{H}-\mathrm{NMR}\left(400 \mathrm{MHz}, \mathrm{CDCl}_{3}\right): \delta 7.40(\mathrm{~d}, J=8.7 \mathrm{~Hz}, 2 \mathrm{H}) ; 7.47(\mathrm{~d}, J=$ $8.7 \mathrm{~Hz}, 2 \mathrm{H}) ; 7.85-7.74(\mathrm{~m}, 2 \mathrm{H}) ; 8.01=7.88(\mathrm{~m}, 2 \mathrm{H}) \mathrm{ppm} ;{ }^{13} \mathrm{C} \mathrm{NMR}\left(100 \mathrm{MHz}, \mathrm{CDCl}_{3}\right) \delta 123.90,127.74,129.31$, $130.23,131.57,133.79,134.62,167.02$ ppm; GC-MS: $\mathrm{C}_{14} \mathrm{H}_{8} \mathrm{ClNO}_{2,} \mathrm{~m} / \mathrm{z} 257.02(\mathrm{M})^{+}$.

2-(4-bromophenyl) isoindoline-1,3-dione $3 \mathbf{i}{ }^{1} \mathrm{H}-\mathrm{NMR}\left(400 \mathrm{MHz}, \mathrm{CDCl}_{3}\right): \delta 7.36(\mathrm{~d}, J=8.7 \mathrm{~Hz}, 2 \mathrm{H}) ; 7.63(\mathrm{~d}, J=$ $8.7 \mathrm{~Hz}, 2 \mathrm{H}) ; 7.80(\mathrm{dd}, J=5.5 \mathrm{~Hz}, J=3.1 \mathrm{~Hz}, 2 \mathrm{H}) ; 7.94(\mathrm{dd}, J=5.5 \mathrm{~Hz}, J=3.1 \mathrm{~Hz}, 2 \mathrm{H}) \mathrm{ppm} ;{ }^{13} \mathrm{C} \mathrm{NMR}(100 \mathrm{MHz}$, $\left.\mathrm{CDCl}_{3}\right) \delta 121.78,123.86,128.04,130.76,131.64,132.28,134.67,166.94$ ppm; GC-MS: $\mathrm{C}_{14} \mathrm{H}_{8} \mathrm{BrNO}_{2}$, m/z 300.97 $(\mathrm{M})^{+}$.

In the FT-IR analysis, the onion peels obtained from a local supermarket (Figure 1a) was compared to onion peels sampled from a local waste disposal site (Figure 1b). As shown in the FT-IR spectrum, the signals at $3393 \mathrm{~cm}^{-1}$ and $1637 \mathrm{~cm}^{-1}$ were attributed to the stretching vibration of hydroxyl groups and carbonyl groups, respectively. Also, all signals shown by the spectrum in Figure 1b (relative intensity, shapes and stretching frequencies) were well preserved compared to those shown by the FT-IR spectrum in Figure 1a. This indicates that there were no considerable changes observed in terms of the chemical structure (functional groups and hydrogen bonding network) of the onion peels recovered from a local waste disposal site compared to onion peels obtained from a local supermarket.

The metal content of the recovered onion peel $(0.8 \mathrm{~g})$ was analysed using ICP-OES and resulted in the following outputs: K $(22927.00 \pm 0.47 \mathrm{ppm}), \mathrm{Na}(14930.00 \pm 0.21 \mathrm{ppm}), \mathrm{Mg}(7896.00 \pm 6.26 \mathrm{ppm}), \mathrm{S}(2225.00 \pm 1.44 \mathrm{ppm})$, $\mathrm{P}(2172.00 \pm 2.13 \mathrm{ppm}), \mathrm{Fe}(1815.00 \pm 1.03 \mathrm{ppm}), \mathrm{Al}(1366.00 \pm 1.07 \mathrm{ppm}), \mathrm{Sr}(300.00 \pm 2.52 \mathrm{ppm}), \mathrm{Mn}(216.00$ $\pm 2.18 \mathrm{ppm}), \mathrm{B}(107.00 \pm 0.09 \mathrm{ppm}), \mathrm{Ba}(53.00 \pm 0.23 \mathrm{ppm}), \mathrm{Zn}(52.00 \pm 0.11 \mathrm{ppm}), \mathrm{Rb}(35.00 \pm 0.02 \mathrm{ppm}), \mathrm{La}$ $(15.00 \pm 0.31 \mathrm{ppm}), \mathrm{Ga}(15.00 \pm 0.12 \mathrm{ppm}), \mathrm{Cu}(13.00 \pm 0.17 \mathrm{ppm})$ and $\mathrm{Pb}(9.80 \pm 0.23 \mathrm{ppm})$.

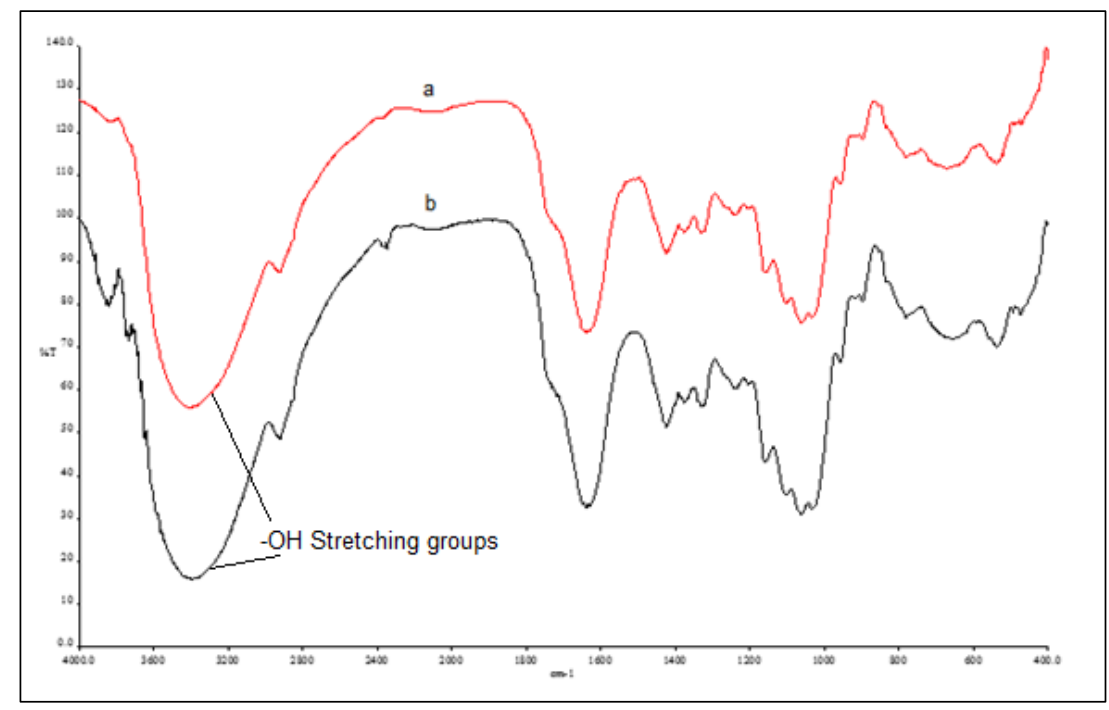

Figure 1. The FTIR spectra of (a) onion peels obtained from a local supermarket and (b) recovered onion peels from a local waste disposal site

For the optimisation of reaction condition, phthalic anhydride $\mathbf{1}$ and aniline $\mathbf{2}$ were chosen as the model starting materials. Initially, phthalic anhydride $1(1.0 \mathrm{mmol})$ was reacted with aniline $\mathbf{2}(1.0 \mathrm{mmol})$ in the presence of 2.0 $\mathrm{mL}$ of $\mathrm{H}_{2} \mathrm{O}$ at $50{ }^{\circ} \mathrm{C}$ to produce the corresponding product, $\mathbf{3 a}$ (Table 1). After 3 hours, the yield of $\mathbf{3 a}$ was found to be poor (Table 1, entry 1). It is worthy to note that when the $\mathrm{H}_{2} \mathrm{O}$ was replaced with WEOPA under identical 
reaction condition, 3a was obtained at a moderate yield (54\%) (Table 1, entry 2). The amount of WEOPA used was also studied. The usage of $2.0 \mathrm{~mL}$ of WEOPA as solvent has produced a good yield of $\mathbf{3 a}(91 \%)$ (Table 1, entry 7). Interestingly, increases in the amount of WEOPA used did give rise to a better yield of 3a (Table 1, entry 7). However, pro-longing the reaction time and increasing in the temperature used did not result in a better of yield of 3a (Table 1, entries 9-10). Based on Table 1, the optimised condition was determined as $2.0 \mathrm{~mL}$ of WEOPA, 8 hours and $80^{\circ} \mathrm{C}$ (Table 1 , entry 7 ).

Table 1. The optimization of reaction condition for the synthesis of $\mathbf{3 a}$

\begin{tabular}{llccc}
\hline Entry & Solvent $(\mathbf{m L})$ & Time (hours) & Temperature $\left({ }^{\circ} \mathbf{C}\right)$ & Yield $(\%)$ \\
\hline 1 & H $\mathrm{O}(2.0)$ & 3 & 50 & 30 \\
2 & WEOPA (0.5) & 3 & 50 & 54 \\
3 & WEOPA (1.0) & 3 & 50 & 60 \\
4 & WEOPA (2.0) & 3 & 50 & 69 \\
5 & WEOPA (2.0) & 3 & 80 & 78 \\
6 & WEOPA (2.0) & 5 & 80 & 84 \\
7 & WEOPA (2.0) & 8 & 80 & 91 \\
8 & WEOPA (3.0) & 8 & 80 & 89 \\
9 & WEOPA (2.0) & 8 & 100 & 90 \\
10 & WEOPA (2.0) & 10 & 80 & 89 \\
\hline
\end{tabular}

Next, the study on the general applicability of the WEOPA catalytic system was carried out using different anilines for the synthesis of isoindoline-1,3-dione derivatives under the optimised condition selected above. As shown in Table 2, the isoindoline-1,3-dione derivatives were obtained at moderate to good yields after silica gel column purification (64-91\% yield). As indicated in Table 2, the anilines bearing the electron-donating groups $\left(\mathrm{CH}_{3}, \mathrm{OCH}_{3}\right.$ and $\left.\left(\mathrm{CH}_{3}\right)_{2} \mathrm{CH}\right)$ afforded the corresponding isoindoline-1,3-dione derivatives $\mathbf{3 b}$-3f at moderate to good yields (Table 2, entries 2-6) compared to anilines bearing electron-withdrawing groups ( $\mathrm{F}, \mathrm{Cl}$ and $\mathrm{Br}$ ) (Table 2, entries 7 9). In addition, the current protocol was considered as unprecedented compared to previous methods, because no solvents and additives were required for the synthesis of isoindoline-1,3-dione derivatives. Moreover, the isoindoline-1,3-dione derivatives were synthesized at a reasonable reaction time. The synthesized isoindoline-1,3dione derivatives were characterised using spectroscopic techniques such as NMR $\left({ }^{1} \mathrm{H}\right.$ and $\left.{ }^{13} \mathrm{C}\right)$ and GC-MS analyses.

Table 2. Isolated yields and influence of the WEOPA catalytic system on the synthesis of isoindoline-1,3-dione derivatives

\begin{tabular}{llccc}
\hline Entry & $\mathbf{R}_{\mathbf{1}}$ & Product & Reaction Time (hours) & Isolated Yield (\%) \\
\hline 1 & $\mathrm{H}$ & $3 \mathrm{a}$ & 8 & 92 \\
2 & $2-\mathrm{CH}_{3}$ & $3 \mathrm{~b}$ & 8 & 74 \\
3 & $3-\mathrm{CH}_{3}$ & $3 \mathrm{c}$ & 8 & 70 \\
4 & $4-\mathrm{CH}_{3}$ & $3 \mathrm{~d}$ & 8 & 73 \\
5 & $4-\mathrm{OCH}_{3}$ & $3 \mathrm{e}$ & 8 & 88 \\
6 & $4-\left(\mathrm{CH}_{3}\right)_{2} \mathrm{CH}$ & $3 \mathrm{f}$ & 8 & 75 \\
7 & $4-\mathrm{F}$ & $3 \mathrm{~g}$ & 8 & 64 \\
8 & $4-\mathrm{Cl}$ & $3 \mathrm{~h}$ & 8 & 66 \\
9 & $4-\mathrm{Br}$ & $3 \mathrm{i}$ & 8 & 68 \\
\hline
\end{tabular}


In addition, we also examined the reusability of the WEOPA catalytic system using the model reaction. After the completion of reaction between phthalic anhydride $\mathbf{1}$ and aniline $\mathbf{2}$, the recovered WEOPA was reused for at least 5 times without any significant loss in catalytic activity (Figure 2).

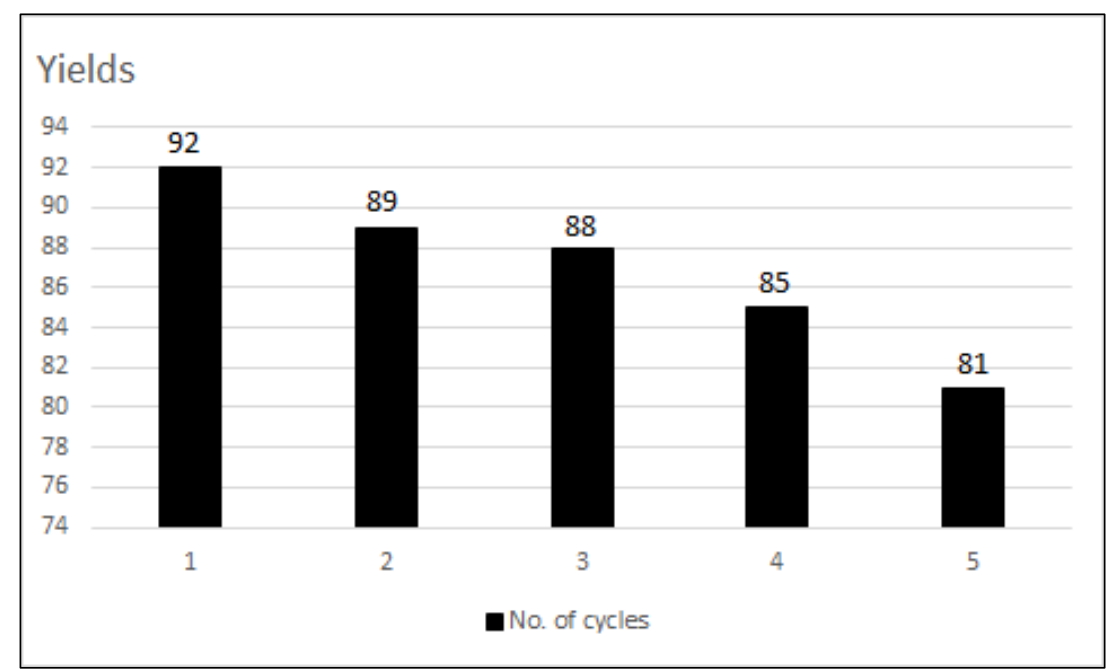

Figure 2. Reactivity of WEOPA based on five runs. Reaction conditions: $1.0 \mathrm{mmol}$ of phthalic anhydride, 1.0 mmol of aniline, $2 \mathrm{~mL}$ of WEOP, $80{ }^{\circ} \mathrm{C}$

At the moment, the mechanism of formation of isoindoline-1,3-dione derivatives catalysed by the WEOPA system is not well understood. However, metal content analysis showed that the onion peel ash consists of metal oxides including phosphorus, magnesium, zinc, manganese and sodium as major elements, accompanied by other minor constituents. We hypothesised that the metals in the WEOPA have facilitated the formation of isoindoline-1,3-dione derivatives and the proposed mechanism was shown in Figure 3.

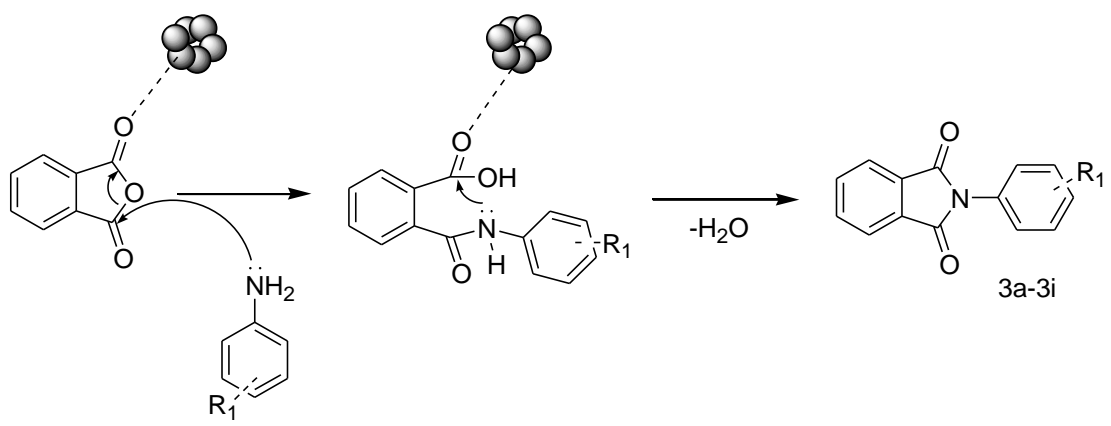

WEOPA catalytic system

Figure 3. Proposed mechanism for the formation of isoindoline-1,3-dione derivatives catalyzed by the WEOPA

\section{Conclusion}

In this work, we have developed a simple, inexpensive and recyclable catalytic system for the synthesis of isoindoline-1,3-dione derivatives. Overall, the yields of the synthesized products were obtained in moderate to good yields (62-91\%). In addition, the WEOPA could be recovered and reused for up to five times without any significant 
loss in catalytic activity. It is worthy to note that the current protocol can be used to synthesize the isoindoline-1,3dione derivatives without the presence of any additives, external acids or solvents. The results of this study might induce researchers to perform organic transformations using the WEOPA as a green solvent.

\section{Acknowledgement}

The authors would like to acknowledge Ministry of Education Malaysia (MOE) for its Fundamental Research Grant Scheme (FRGS 59499).

\section{References}

1. Chassaing, S. and Beneteau, V. (2017). Zeolite as green catalysts for organic synthesis: The cases of $\mathrm{H}-, \mathrm{Cu}-\&$ Sc-zeolites. Current Organic Chemistry, 21(9): 779-793.

2. Andersen, J. and Mack, J. (2018). Mechanochemistry and organic synthesis:from mystical to practical. Green Chemistry, 20(7): 1435-1443.

3. Kan, S.-Y., Yiong, W. S., Yong, F. S. J. and Chia, P.W. (2017). Synthesis of benzothiazole derivatives using ultrasound probe irradiation. Malaysian Journal of Analytical Sciences, 21(6): 1219-1225.

4. Asseri, S. N. A. R. M., Tan, S. H., Mohamad, W. N. K. W., Poh, S. C., Chia, P. W., Kan, S.-Y. and Chuah, T. S. (2017). $\mathrm{MgCl}_{2}$ as efficient and inexpensive catalyst for the synthesis of 1,4-dihydropyridine derivatives. Malaysian Journal of Analytical Sciences, 21(1): 13-19.

5. Waseem, M. A., Srivasta, A., Srivasta, A. and Siddiqui, I. (2015). Water and ionic liquid synergy. A novel approach for the synthesis of benzothiazole-2 (3H)-one. Journal of Saudi Chemical Society, 35(1): 68-82.

6. Li, C.-J. and Chen, L. (2006). Organic chemistry in water. Chemical Society Review, 35(1): 68-82.

7. Kucherenjo, A., Kostenko, A., Zhdankina, G. M., Kuznetsova, O. Y. and Zlotin, S. G. (2018). Green asymmetric synthesis of Warfarin and Coumachlor in pure water catalyzed by quinoline-derived 1,2-diamines. Green Chemistry, 20(3): 754-759.

8. Han, M. Y., Lin, J., Li, W., Luan, W. Y., Mai, P. L. and Zhang, Y. (2018). Catalyst-free nucleophilic addition reactions of silyl glyoxylates in water. Green Chemistry, 20(6): 1228-1232.

9. Noshiranzadeh, N., Emami, M., Bikas, R. and Kozakiewicz, A. (2017). Green click synthesis of $\beta$-hydroxy-1, 2, 3-triazoles in water in the presence of a $\mathrm{Cu}$ (II)-azide catalyst: a new function for $\mathrm{Cu}$ (II)-azide complexes. New Journal of Chemistry, 41(7): 2658-2667.

10. Banerjee, B. (2017). Recent developments on ultrasound assisted catalyst-free organic synthesis. Ultrasonics Sonochemistry, 35: 1-14.

11. Miklós, F. and Fülöp, F. (2016). A simple green protocol for the condensation of anthranilic hydrazide with cyclohexanone and n-benzylpiperidinone in water. Jornal of Heterocyclic Chemistry, 53(1): 32-37.

12. Sarmah, M., Mondal, M. and Bora, U. (2017). Agro-waste extract based solvents: emergence of novel green solvent for the design of sustainable processes in catalysis and organic chemistry. ChemistrySelect, 2(18): 5180-5188.

13. Boruah, R. P., Abdul, A. A., Mitali, C., Bishwajit, S. and Diganta, S. (2015). Pd(OAc) $)_{2}$ in WERSA: A novel green catalytic system for Suzuki-Miyaura cross-coupling reactions at room temperature. Chemical Communications, 51(57): 11489-11492.

14. Saikia, B., Boruah, P. R., Ali, A. A. and Sarma, D. (2015). 'On-water'organic synthesis: a green, highly efficient, low cost and reusable catalyst system for biaryl synthesis under aerobic conditions at room temperature. RSC Advances, 5(63): 50655-50659.

15. Dewan, A., Sarmah, M., Bora, U. and Thakur, A. J. (2016). A green protocol for ligand, copper and base free Sonogashira cross-coupling reaction. Tetrahedron Letters, 57(33): 3760-3763.

16. Surneni, N., Barua, N. C. and Saikia, B. (2016). Application of natural feedstock extract: The Henry reaction. Tetrahedron Letters, 57(25): 2814-2817.

17. Saikia, B. and Borah, P. (2015). A new avenue to the Dakin reaction in $\mathrm{H}_{2} \mathrm{O}_{2}$-WERSA. RSC Advances, 5(128): 105583-105586.

18. Choi, I. S., Cho, E. J., Moon, J.-H. and Bae, H.-J. (2015). Onion skin waste as a valorization resource for the by-products quercetin and biosugar. Food Chemistry, 188: 537-542.

19. Marshall, R. E. and Farahbakhsh, K. (2013). Systems approaches to integrated solid waste management in developing countries. Waste Management, 33(4): 988-1003. 
20. Nile, S. H. and Park, S. W. (2013). Total phenolics, antioxidant and xanthine oxidase inhibitory activity of three colored onions (Allium cepa L.). Frontier in Life Science, 7(3-4): 224-228.

21. Sharma, K., Mahato, N., Nile, S. H., Lee, E. T. and Lee, Y. R. (2016). Economical and environmentallyfriendly approaches for usage of onion (Allium cepa L.) waste. Food Function, 7(8): 3354-3369.

22. Gao, S., Li, L., Geng, K., Wei, X. and Zhang, S. (2015). Recycling the biowaste to produce nitrogen and sulfur self-doped porous carbon as an efficient catalyst for oxygen reduction reaction. Nano Energy, 16(2015): 408418.

23. Pontrello, J. K., Allen, M. J., Underbakker, E. S. and Kiessling, L. L. (2005). Solid-phase synthesis of polymers using the ring-opening metathesis polymerization. Journal of American Chemical Society, 127(42): 1453614537.

24. Sortino, M., Garibotto, F., Fihlo, V. C., Gupta, M., Enriz, R. and Zacchino, S. (2011). Antifungal cyctotoxic and SAR studies of a series of $N$-alkyl, $N$-aryl and $N$-alkylphenyl-1,4-pyrroledinones and related compounds. Bioorganic Medicinal Chemistry, 19(9): 2823-2834.

25. Bouissane, L., Sestelo, J. P. and Sarandeses, L. A. (2009). Synthesis of 3,4-disubstituted maleimides by selective cross-coupling reactions using indium organometallics. Organic Letters, 11(6): 1285-1288.

26. Hurd, C.D. and Prapas, A.G. (1959). Preparation of acylcic imides. Journal of Organic Chemistry, 24(3): 388392.

27. Walker, M. A. (1995). A high yielding synthesis of N-alkyl maleimides using a novel modification of the Mitsunobu reaction. Journal of Organic Chemistry, 60(16): 5352-555.

28. Chen, D. C., Ye, H. Q. and Wu, H. (2007). A more efficient synthetic process of $N$-arylphthalimides in ionic liquid $[\mathrm{bmim}]\left[\mathrm{BF}_{4}\right]$. Catalysis Communications, 8(10): 1527-1530.

29. Habibi, D. and Pordanjani, H. M. (2017). Phthalimide-N-sulfonic acid, an efficient catalyst for the synthesis of various isoindoline-1,3-dione derivatives. Chemical Papers, 71(11): 2293-2299. 